\title{
Fracking Expertise:
}

\section{How Interest Groups Used Expert Claims in Pennsylvania's Fracking Controversy around Act 13}

\author{
Alina Dausendschön
}

\section{Introduction}

Hydraulic fracturing for shale gas extraction, also called fracking, is steadily growing as an energy source for the United States. Despite the technology's promising economic opportunities, its application remains highly debated due to reported pollution incidents and uncertainties regarding long-term environmental and public health impacts. The regulation of fracking in the US is subject to federal state legislation. When the Commonwealth of Pennsylvania changed its fracking regulation in 2012, this sparked off a new round of debate. House bill 1950, often referred to as Act 13, expanded the possibilities for fracking in all areas of the state, even in housing districts and sensitive areas of high environmental value. Outraged, the affected municipalities decided to question the legality of the bill before court in March 2012. The case was closed in February 2014, when the Supreme Court judged the zoning prohibitions unconstitutional in a final say (Goho, 2012; case Robinson Township, J-127A-D-2012).

The controversy revolving around Act 13 showed a clear split between two camps: On the one hand, the Commonwealth of Pennsylvania as the creator of the bill grouped together with the gas industry which would have benefited of most of the changes introduced. On the other hand, the municipalities and environmentalist groups feared environmental degradation due to the facilitated spread of fracking and hence opposed the new law. Both of the opposing alliances based their arguments on expert judgments from different sources. This study of the controversy between the alliances focuses on the private actors rather than the public authorities, i.e. the gas industry and environmentalists rather than Pennsylvania State and the municipalities. As a representative of the gas industry, the Marcellus Shale Coalition (MSC) is examined, since it is an umbrella organization representing the interests of over 200 companies involved in fracking. For examining the environmentalist groups, this paper analyzes the Delaware Riverkeeper Network (DRN), 
because it is a major group engaged in public advocacy. These private groups merit special attention, because they have little institutional power in the formal policy-making process and the eventual implementation, but are directly affected by policy outcomes. This means that they have a particular interest in shaping the public debate in order to advocate for their interests and influence policy indirectly. Unlike the public authorities, they only have this tool at their disposal to shape policy.

Because expert judgments of risk, safety and benefits play a prominent role in the public debate around fracking in Pennsylvania, this paper investigates the ways in which the gas industry and environmentalists use expertise strategically to support their claims. This means examining how they use scientific experts as external sources; while also analyzing how these groups strive to present themselves as practical experts in the debate. In the controversy at hand, expertise can not only refer to scientific and practical expertise, but it can also be subdivided into different fields of expertise such as the environment, society and economics; the backgrounds of the experts cited in the controversy reflect this diversity. Since the two groups try to frame the controversy of the bill in different ways, they tend to refer to such different fields of expertise. As a result of assuming a broad perspective on expertise, this paper captures a wide spectrum of claims made in the controversy.

This paper first provides some insights into fracking practice in Pennsylvania, the technology's opportunities, its risks and remaining uncertainties. It then sheds light on the controversy triggered by Act 13. Next, the paper outlines the theoretical background on the use of expert knowledge as a source of authoritative knowledge. The main analysis consists of two parts: The first considers the use of scientific experts from outside as sources of authority, while the second focuses on the interest groups as practical experts. Finally, the conclusion returns to this study's main claim. This central argument is that the two private groups use scientific expertise to base their arguments on and interweave it with what they present to be their own practical expertise. By constructing an image of themselves as possessing specialist knowledge, they gain authority and act as experts themselves.

\section{Fracking the Marcellus Shale}

The Marcellus Shale of the Appalachians is a natural gas play located at the east coast of the US. The magnitude of the gas play has been roughly known to geologists for decades, but until the early 2000s, extraction was prohibitively costly (Arthur, Bohm \& Layne, 2008). This changed due to a combination of political changes and technological advances. A fracking boom followed suit: The first well in Pennsylvania was drilled in 2003 (ibid.); as 
soon as in 2010, Pennsylvania counted 1385 drilling sites and 3314 drilling permissions (Brasier et al., 2011).

In the process of hydraulic fracturing, a well is drilled into the ground. Since natural shale gas formations lock the gas in the pores of horizontal impermeable stone layers, drilling a vertical hole provides only limited exposure and hence curtails the drilling impact. Horizontal fracturing addresses this by drilling down to the shale and then continuing the drill horizontally for up to $1.5 \mathrm{~km}$ (New York State Department of Environmental Conservation). Then, a fracking fluid consisting of water, chemicals and sand is pumped into the well at high pressure to fracture the stone along the drill and free the natural gas from the stone pores. The chemical additives can serve several purposes, such as preventing corrosion or improving viscosity, while the sand is used as a propping agent, keeping open the fissures to secure the gas flow-back (Soeder \& Kappel, 2009).

The supporters of fracking claim that the thorough pre-fracking tests secure the safety of the process (Harper, 2008). Moreover, some geologists argue that the shale acts as a natural barrier against leaks, and fractures across multiple stone layers (e.g. into a ground water layer) are unlikely to occur due to the physical characteristics of the stone (Arthur et al., 2008). Additionally, casing and cementing of the borehole are said to offer sufficient protection, as the small number of spills indicates (ibid.). Moreover, the burning of the extracted gas is comparatively clean, generating approximately $50 \%$ of the $\mathrm{CO}_{2}$ emissions which are produced when burning coal (Kargbo, Wilhelm \& Campbell, 2010). At the same time, there are also a number of concerns. Some scholars fear air pollution due to flaring of excess gas, venting and heavy traffic (Goho, 2012). There is also growing evidence of seismicity induced by fracking (Kargbo et al., 2010). The major concern, however, are the possible effects on water and surrounding ecosystems. Depending on the depth of the well, between 7.8 and 38 million liters of fracking fluid, i.e. water and additives, are needed to complete a single operation (ibid). Since these huge quantities of water are usually acquired on site, the fragile ecosystem of the Delaware could suffer serious damage caused by water extraction (ibid;). Moreover, the flow-back water from the wells is enriched with fracking chemicals and naturally occurring salts and radioactive elements from the deep stone layers and hence highly ecotoxic (Kargbo et al., 2010). Neither is onsite storage of the flow-back a safe long-term solution nor are water-treatment facilities currently prepared for the large quantities of contaminated water (ibid.).

Due to a lack of empirical data, uncertainty remains about the likelihood of many hazards to occur in fact. Nevertheless, their destructive potential yields sufficient reasons for many citizens, policy makers and environmentalists to be alarmed about environment and public health impacts. This can explain why people want to protect fragile ecosystems 
such as the Delaware Basin from fracking. Against this backdrop, the explosive potential of Act 13 shows clearly. When fracking emerged in Pennsylvania, it was regulated by Pennsylvania's Oil and Gas Act (POGA) which allowed for local planning. This meant in practice that municipalities could use zoning ordinances to restrict fracking in certain areas which they considered protection-worthy. In February 2012, Governor Corbett's government passed Act 13 amending POGA. The bill contained a number of highly controversial provisions, of which the most prominent was the preemption of the local zoning authority combined with a fiscal punishment mechanism for non-compliance (Smith \& Ferguson, 2013). Rabe \& Borick (2013) argue that Governor Corbett made quite clear that this amendment was supposed to aid the gas industry.

As a response to the bill, seven municipalities, the Delaware Riverkeeper Network and a physician joined forces to file a lawsuit against the prohibition of zoning ordinances in March 2012. When the court judged the provision unconstitutional, the State of Pennsylvania challenged the decision before the Supreme Court. Their appeal was supported by a number of amicus briefs from natural gas producers. Eventually, the final judgment in February 2014 (case Robinson Township, J-127A-D-2012) upheld the unconstitutionality of the zoning prohibition, highlighting the violation of Article I Section 27 of the Pennsylvania Constitution which states: "The people have a right to clean air, pure water, and to the preservation of the natural, scenic, historic and esthetic values of the environment." This judgment is clear evidence that the Supreme Court regarded hydraulic fracturing as a potential threat to the environment and viewed the local zoning authority as a necessary tool to protect fragile areas on a case-by-case basis. While the legal dispute was limited to court, the affected parties used the public arena to exchange a wide array of arguments based on expert claims. The debate about what seems to be a technical discussion about regulatory practice blends in with a much larger debate about hydraulic fracturing. In this debate, expert knowledge about the practice and impacts of fracking plays a crucial role in making a substantial argument.

\section{From Lays to Practical Experts}

The major curiosity about the concept of expertise is that there is no coherent one generally agreed upon; those developed in academic literature vary widely in their level of inclusion. A group of Australian risk experts offers a very broad definition, claiming that expert knowledge is defined as "substantive information on a particular topic that is not widely known by others. An expert is someone who holds this knowledge and who is often deferred to in its interpretation" (Martin et al., 2011, p.2). Much academic literature, however, employs the term "expert" rather as a synonym of "professional 
scientist" working in research (see for instance Pielke, 2007; Hilgartner, 2000). The variety of definitions of expertise emerges because expertise "is not simply about one person's skills being different from another's. It's also grounded in a fierce struggle over ownership and legitimacy" (Hartelius, 2008, p.2). This is a crucial observation: Expertise is not only the possession of knowledge, but it has a value. It lends authority to a claim, power to the 'expert' and legitimacy to who is making the claim. Much research has been done on the (appropriate) role of scientific experts in policy and politics in various fields of study. Two scholars who depart from this, arguing for the consideration of non-scientific knowledge in policy-making, are the policy analyst from Duke University, Frank Fischer (2000), and the British STS scholar Brian Wynne (1996). Neither of the scholars, however, further distinguishes within the apparently homogeneous group of lays. The influential sociologists Harry Collins and Robert Evans (2007) propose regarding expertise rather as a ladder, on which only the highest step is scientific expertise from active research. Before reaching this level, individuals can become interactional experts by internalizing the specialist tacit knowledge of contributory (scientific) experts.

Drawing back on Hartelius' remark that being regarded as an expert has a certain value, some lays may have a vested interest in being regarded as non-scientific experts by other lays. As experts, they would be referred to as a credible source, which would give them a special standing among all other lays. Therefore, this paper suggests that for understanding strategic self-presentation of non-scientific'experts' it is useful to introduce the notion of a practical expert next to the traditional scientific expert. Such a practical expert is considered to be a group or individual who claims to have substantial knowledge which is not widely available to others and which results from the practical involvement with a topic. Such knowledge is presented to stem from actual working practice and experience in the field. It can include scientific knowledge acquired before becoming or through being active in a field; it is, however, not restricted to scientific knowledge. Similarly, a scientific expert can also claim to possess some practical expertise through active participation, while still remaining mainly a scholar. The concept of the practical expert can add to the understanding of the use of expert claims in an environmental controversy, because it explains the logic behind interest groups presenting themselves as experts (although not being scientists) as distinguished from the broad category of lays in order to gain an authoritative say. 


\section{Expert versus Expert}

\section{Using scientific experts}

Before examining how the DRN and the MSC acted as practical experts in the fracking controversy, this section sheds some light on their use of scientific expertise from external sources. Although the groups may have acquired a certain degree of scientific knowledge through their involvement with the topic, there were certainly more credible expert sources they could refer to when making claims about scientific arguments. Those scientific experts give authority to the groups' claims, as they provide the scientific base in this technical discussion. Their un-critical reliance on science for 'neutral facts' rests on the assumption that science is value-free, which has dominated people's conception of science for centuries (Kincard, Dupré \& Wylie, 2007).

Two broad groups of external scientific experts can be distinguished here: Public authorities (on federal and on state level) and academia. The federal bodies referred to are mostly the US Environmental Protection Agency and the US Department of Energy (e.g. MSC, 2013a), while the state authorities range geographically and subject-wise from the Pennsylvania Department of Environmental Protection to the Dakota Resource Council (MSC, 2012a; Carluccio \& Bloom, 2012). However diverse the regulatory power and the institutional interest, these sources are referred to by both DRN and MSC. While other explanatory variables cannot be excluded, it suggests itself that the groups draw on the institutional trust in these public agencies. Research suggests that institutional trust is built on "the degree of perceived fairness and impartiality of the institution" (Rothstein \& Stolle, 2003, p.192). If DRN and MSC assume that public trust in these state bodies is high, using their scientific expertise represents fair and impartial data and judgments. This assumption is examined more in detail below. In academia, the local universities Pittsburgh University and Delaware University are frequent sources of scientific expertise, as well as university studies from other fracking areas, such as those from TU Austin, Texas (e.g. MSC, 2013a). More even than the public authorities, they represent "pure" science, the ideal of value-free, neutral scientific findings (Kincaid et al. 2007). This view could be condensed to the simple statement that "(t)he job of science is to tell us the facts" (ibid., p.4). This attitude becomes clear throughout the two interest groups' use of scientific expertise in the debate of Act 13.

Relating the two interest groups' use of scientific expertise in the debate to each other reveals three situations which emerge throughout the controversy. First, each group refers to a number of scientific experts from academic backgrounds which the other group does not consider. Second, in spite of having opposing claims, they often refer to the same scientific experts. Third, they do not place much attention on the specific scientific experts while using their findings. 
In large parts of the debate, DRN and MSC avoid each other's arguments by stressing different elements of the disputed bill. This framing entails that they often align themselves with scientific experts from various academic fields. In its Shale Truth Interview Series, DRN presents a number of experts from universities, consultancies and think tanks. Presented with their academic titles, they provide the audience with "facts" on issues as diverse as landscape restoration, the dangers of the mechanical process of fracking and economic damage (Van Rossum, 2013a). MSC, by contrast, refers mainly to studies of the Energy Institute of UT Austin for water issues and to economists from the Massachusetts Institute of Technology, Cornell University and other universities for the positive impacts on manufacturing and job creation (McChesney, 2012). Their argumentation hence rests on the scientific expertise mainly of geologists, hydrologists and economists. MSC's campaign "Just the Facts" clearly reflects the paradigm of value-free science which can be drawn on at will for the provision of scientific expertise (MSC, 2013b). Although extensive research in the fields of STS, philosophy of science and sociology of science questions this idea, the two interest groups do base their claim to authority on the assumption of neutral facts.

Although the substance of their arguments differs considerably, DRN and MSC often base their claims on finding of the same scientific experts. These are in most cases statistical data of the Pennsylvania Department of Environmental Protection, the US Geological Survey and the US Environmental Protection Agency. While DRK uses their data to stress uncertain risks for groundwater and to quantify incidents of chemical spills, MSC refers to these bodies to underline the claim that groundwater determination due to fracking has never been proven (MSC, 2013a). It does not seem relevant whether the regulatory approach of the public authority is for or against fracking and municipal zoning. The US Environmental Protection Agency, for instance, is referred to by DRN to make a point that radioactivity in Marcellus Shale wastewater exceeds radioactivity in other formations (Carluccio \& Bloom, 2012). MSC, by contrast, refers to the agency to bolster their claim that no private water wells have been contaminated by fracking (Wolfgang, 2012). As those claims are not related to each other, they can be based on findings of the same scientific expert. Both seem to use public trust in the experts' neutrality or value-free production of scientific facts as a resource, as it adds credibility to their arguments.

While in a part of the cases, the scientific experts are explicitly named and their findings reproduced in detail, much of the debate remains at a very general level at which the scientific expert is not in the focus. This can be observed in various ways. Firstly, they are not explicitly mentioned by name. Both groups employ generic terms such as "science", "scientists", "a hydrologist" or institutes, such as in "a study by the University of Delaware" 
(Shale Gas Outrage, 2012). Secondly, particularly DRN often even refers to findings and mention the provider of such scientific expertise only in a footnote (ibid.). Both the general terms and the banning of the experts from the main text correspond to the tendency of avoiding too technical a discussion. Rather than confusing their lay audience with names of chemicals and the density of stone layers, the interest groups often simplify the messages, which is well-illustrated by MSC's tweets such as "New Study Finds that Hydraulic Fracturing is safe http://t.co/uLKurUu7 via IERenergy \#ShaleGas \#Marcellus" (MSC, 2012). The sole fact that there is a scientific study which yielded a result is sufficient for the argument.

\section{Being practical experts}

\section{Constructing Practical Expertise}

Next to using a variety of scientific experts as external sources of objective, 'value-free' scientific facts, the two groups also constructed an image of themselves as practical experts. Rather than leaving the right over a serious claim to others from specific academic backgrounds, they portrayed themselves as having relevant specialist knowledge in order to gain authority in their arguments. This relevant specialist knowledge, they argue, stems from extensive experience in matters concerned with fracking and crucial involvement with practices. They claim that such practical experience endows them with particular insights which distinguish them from simple interested citizens.

The Delaware Riverkeeper Network (DRN) regularly offers self-descriptions as "a leader in regional watershed issues (a point well demonstrated by the achievements in this report)" (DRN, 2012a, p.2). The leader role stemming from active involvement with studies, restoration and legal engagement with issues related to the Delaware can be interpreted as a call for being acknowledged as a crucial player with expert knowledge. Statements such as "giving a voice to the Delaware, its tributaries and all the communities that appreciate and depend upon them" (ibid., p.11) imply that the group wants to be seen as an expert on community needs and preferences as well. Additionally, DRN claims that "(w)e help decisionmakers (sic.) and citizens consider and address threats in their own communities" (DRN, 2013, p.3). This role is based on the assumption that DRN possesses knowledge which decision-makers and citizens do not have access to and which is relevant for them. In sum, DRN depicts itself as a practical expert in all matters related to the Delaware due to its practical involvement, needed by the public to provide expertise.

Similar to DRN, the Marcellus Shale Coalition attributes to itself expert status (MSC, Request a Speaker). This expertise is presented to be about the technical mitigation of 
environmental impacts of fracking; yet, it also includes other technological issues related to the natural gas industry. In fact, visitors of the group's homepage can book a speaker with "decades of experience and expertise in issues related to the natural gas industry and Marcellus Shale development" (ibid.), which directly links the group to long-term practical experience and expertise. Apart from this self-presentation as someone who provides expertise, the statement also underlines that public agencies recognize the group's relevant practical expertise. This recognition as a practical expert surfaces time and again on MSC's blog, where a regular section "What they are saying" compiles extracts from newspaper articles where MSC is cited as an expert. This serves to provide evidence that not only the group itself but also others consider the group a practical expert.

\section{Using Practical Expertise}

Being recognized as an expert enables individuals to give an 'expert judgment' that is acknowledged to be founded on substantial and relevant knowledge. This is what the groups make use of for the debate of Act 13. They use this leverage in a number of activities that serve to underscore their position: to frame the issue; to act as an educator for the public; to add to the existing pool of knowledge; to network with other practical experts; to rebuke the other side's arguments; and to sketch their position as emerging as the only sensible one. Most of these activities, and particularly the latter two, are interesting cases of the interplay of scientific and practical sources of expertise.

The underlying strategy in the entire controversy around Act 13 on both sides is framing the controversy in a way which suits the groups' interests. These different framings entail that diverging fields of expertise become relevant. DRN issued a number of fact sheets in which they sum up what they consider the main facts of the bill. The group uses these summaries to stress the points it considers noteworthy. For instance, clarifications as in this example: the bill "extinguishes all existing zoning and planning ... anywhere in a municipality (including residential neighborhoods, by schools, hospitals, and day care centers, and sensitive natural and public resources)" (DRN, 2012b, p.1). The brackets at the end clarify the implications DRN deems relevant. In this case, the attention is directed towards the implications for local communities. As the DRN actively constructs an image of itself as a practical expert on the local environment and population, such framing puts Act 13 within the area of the group's expertise.

DRN's strategy to interpret the bill entails also a whole discourse of what it is not about. In an open letter, the group asks State Senator Chuck Mcllhinney to retract a statement about Act 13 made in public, because "your interpretation ... is dead wrong" (Van Rossum \& Carluccio, 2012a, p.4). The Senator had claimed that all communities would 
benefit from the bill due to the newly established impact fee (ibid.). These statements firmly reject an economic framing of the issue as put forward by the opposing group. By presenting other framings of the bill as putting the focus on irrelevant aspects, DRN also depicts the expertise drawn on within those other frames as irrelevant.

MSC, too, framed the controversy in a particular way. Experienced with regulatory matters, the group asserts that "states like Pennsylvania continue to raise the bar on regulatory requirements" (MSC, 2012a), because those were standardized by the bill. The group claims that clean-burning gas is "proving that we don't have to choose between our environment and our economy" (ibid.). MSC stresses the job creation, the support of US manufacturing and environmental benefits from the lower carbon emissions of natural gas compared to coal. As Klaber puts it, the amount of impact fees collected from fracking activities is a "stark reminder that these benefits should not be tempered by policies that discourage ... natural gas development" (MSC, 2013c). Hence, the MSC highlights the need for expertise regarding regulatory safety measures and economic impacts of fracking, which the group argues to possess.

These two framings of the bill put forward by the groups make sense not only because they support their respective views on the issue, but also because they correspond with their practical expertise. In fact, there seems to be a co-construction of the own fields of practical expertise and the framing of Act 13. The framing of the bill is done in such a way to emphasize those issues which lie within the area of expertise of the groups. Meanwhile, the expertise of the groups is also presented as matching the need for particular expert knowledge in the controversy.

A practice closely interwoven with the framing of Act 13 is both groups' action as an educator. In addition to selecting pieces of information they deem relevant in the matter based on their longtime experience, they present themselves as experts who provide this information to the public in order to advance understanding. Their status as practical experts deeply involved with the practices and impacts of fracking gives the groups the power to speak to people on their own account rather than having to rely on outside experts.

The environmentalist group openly states its mission as "DRN continues to engage and educate municipalities about the harms of Act 13" (DRN, 2012a, p.7). It does so by organizing news events to educate people (Garber, Van Rossum, Feridun, Bernhardt \& Bloom, 2013) and publishing a host of information notes with titles such as "The Truth about Natural Shale Gas Extraction in the Upper Delaware River Watershed:What You Need to Know" (DRN, 2009). The framing of Act 13 as a hazard for the environment renders DRN, as environmental expert, a suitable educator in this context. In various appeals to their 
audience to oppose the bill, the group even provides the reader with arguments, stating that "you can use the analysis and talking points below to prepare your comments" (Berks Gas Truth et al., 2014). Years of practical involvement with such comments are arguably a thorough basis for providing recommendations to un-experienced citizens. Here, DRN draws on two expert images of itself: It provides expertise about the environmental implications of Act 13, while also acting as an expert on how to pressurize the legislator.

MSC also acts as an educator for the people. The speaker of Seneca Resources, a member of MSC, states in a newspaper article, "I understand that they (the critics) don't really understand what we're actually doing here and the safety steps we go through for preventing environmental instances" (WJACTV, 2012). With this, he indicates that opposition to fracking is based solely on ignorance, and real experts (i.e. MSC) are needed to provide relevant information. The frequent hashtag \#LearnAboutShale in the group's tweets and the coalition's own education homepage learnaboutshale.org both belong to the Learn About Shale Initiative. In this way, MSC uses its image as an expert on regulatory practice to disseminate information and convince their audience of the safety of fracking. Their expert status is also the foundation of a number of recommended practices issued for several phases of fracking, such as water management practices or monitoring (MSC, 2012b). On the basis of their status as practical experts on best practices in fracking, the group members can act as a counsel who is knowledgeable about risk-containment strategies.

The two interest groups act as practical experts on the basis of their experience most of the time, but they also cooperate intimately with scientific experts in public. Both groups bring forward scientific studies in order to add to the pool of scientific knowledge. DRN, for instance, publicly announced in a press release a report about the impact of shale gas drilling on endangered bat populations, which was authored by a biologist from Bat Conservation International (Van Rossum \& Hein, 2012). The scientific contribution of MSC is an "extensive study" in cooperation with the Pennsylvania Independent Oil and Gas Association on Naturally Occurring Radioactive Material (NORM) and Technologically Enhanced NORM (MSC, 2013d). By advancing such research, the two interest groups blur the lines between scientific and practical expertise; this effects that their practical expertise does not appear to be the opposite of scientific knowledge, but rather as related to it.

Another eminent element of the groups' action as practical experts is networking with their peers. This is surely not a singular practice of practical experts in particular, but it is still a noteworthy part of their action in the debate. DRN regularly publishes press statements jointly with other interest groups from different fields. Most of them are environmental groups, such as Earthworks (Berks Gas Truth et al., 2014). Some, however, come from other backgrounds, as Democracy for America (Garber et al., 2013). 
In those publications, the groups refer to each other as expert sources and thereby back up their own claims while also lending each other credibility. This is a less prominent feature of MSC's action, as the group is already an umbrella organization of companies. Nevertheless, it hosted the Shale Insight Convention, where companies, associations, academic and public administrators came together (MSC, 2013e). In this context, too, the MSC seized the opportunity to act as an expert among the other participants and mutually reinforce the image as experts who are referred to by other experts.

Another crucial part of the debate of Act 13 is rebuking the other side's experts. The groups present the counter claim as unreasonable and not founded on facts. In this strategy, the action as practical expert is closely linked with the use of external experts. The groups show themselves as able to judge the credibility of sources and the value of the other side's arguments, while simultaneously, they often draw on scientific expertise to add to their claims.

DRN criticizes the regulatory bodies' information on the one hand and the gas industry's arguments on the other hand. Addressing the public bodies, it denounces the flawed reasoning of the Pennsylvania Department of Environmental Protection (PA DEP) when arguing for the zoning prohibition and accuses the department of having doctored laboratory reports (Steinzor, Van Rossum, Carluccio, Bloom \& Hvozdovich, 2012). With regard to the gas industry, the Delaware Riverkeeper states that DRN is "working to expose the truth against a tide of money and heavyhanded (sic.) corporate influence" (Van Rossum \& Carluccio, 2012C). She warns her audience not to "let fast talk by drillers and their supporters ... cloud the truth about Act 13" (DRN, 2012c, p.2). The overall claim is hence that the other side does not provide reliable expertise, while DRN does.

MSC engages even more heavily in discrediting the opposite side's expert claims, arguably because they are in a defensive position, being accused of polluting the environment. Tweets such as “@EPAgov water well tests 'found NONE with unsafe levels of contamination tied to fracturing' " (MSC, 2012d) directly address claims made by the opposing groups that in Dimock, PA fracking decreased water quality. One of the group's favorite newspaper articles titled Experts: Some Fracking Critics Use Bad Science (Begos, 2012) which was re-posted on their website several times reflects a simple, but effective message: The other side's experts are not good experts. Furthermore, MSC publishes a host of blog entries in the format FEAR/ CLAIM - FACT (MSC, 2013b), in which it vitiates claims made by the opposing side. MSC does use scientific findings to support its counterarguments, but the sheer fact that the group dares to question the methodology of a study by Duke University (MSC, 2013a) shows that it considers itself expert enough to issue substantial arguments. 
As a result of the efforts building up their arguments both groups come to the same conclusion: Their position is emerging as the only reasonable. Similar to the deconstruction of the counter side's arguments, use external sources of scientific expertise extensively; yet, their own practical expert status lends them authority to draw conclusions based on their alleged substantial insights into the topic. Aligning themselves with scientific experts hence adds to their status as experts, since their position appears to be more than casual knowledge unsupported by science, and merges the 'facts' into an undeniable conclusion.

DRN's stance is well-expressed by their reference to the field organizer form Environment New Jersey who states that “( $\mathrm{t}$ )he numbers (of polluting incidents) don't lie-fracking has taken a dirty and destructive toll on our environment" (DeRosa, 2013, p.1). From their point of view, they have sufficiently proven - drawing both on scientific and own practical expertise - that fracking is dangerous and should be subject to municipal zoning. While scientific expertise helped to draw some of the technical conclusions (e.g. the amount of water needed of a frack), DRN draws on its practical expertise regarding water issues - i.e. its year-long observations of spills, its work to protect private water wells and its surveillance of water quality in the Delaware - to make the overall argument against fracking throughout the state.

MSC argues that a broad scientific consensus, history and day-to-day activity (i.e. experience) have made increasingly clear that fracking benefits the environment as well as the economy. They refer to the producer of the pro-fracking film Frack Nation, Ann McElhinney, who claims that "(s)ome people say, 'There's all kinds of truth.' That's wrong. There's all kinds of opinion. There isn't all kinds of truth. There's just the truth" (cited by Hicks, 2012). This truth is claimed by MSC, as they contend to have the expertise necessary to distinguish truth from opinion and present it to their audience.

\section{Conclusion}

Expert knowledge is crucial to base a claim on, because it lends substance and legitimacy to an argument. The Delaware Riverkeeper Network and the Marcellus Shale Coalition, however diverse their interests, seem to employ expert claims in rather similar ways in the debate of Act 13. The two interest groups use scientific expertise from public authorities and academia to make claims on the 'neutral' facts of the technology's impacts on environment and economy. This reflects an image of value-free science which lends authority to the user, as the findings cannot be questioned. A closer look at the scientific experts they refer to reveals that there are three types of references. First, they refer to specific scientific experts which the other group does not refer to, as they make 
claims over different aspects of the bill. Second, they refer to the same scientific experts although their arguments are opposed to each other, which shows how central the alleged neutrality of the expert is to their argument. Third, they often place the implications of scientific findings in the foreground without putting much emphasis on the scientific expert themselves. This is rooted in the (over-)simplification of the complex issue.

A major finding of this paper, however, is that the groups work to place themselves in an expert position too. The development of the notion of the practical expert serves to gain deeper insights into how the groups act as experts in the controversy. Through their communication strategies, they construct an image of themselves as possessing substantial knowledge which lays and even policy-makers depend on. This knowledge is not presented as stemming from academic education, but intensive practical involvement with the fracking industry and the environment for a long time. In their self-presentation, DRN and MSC are practical experts in the fracking debate who need to be heard. This image as practical experts enables them to act from an expert position rather than backing up each of their claims with an expert judgment from outside. Having expert authority, they frame the meaning of the bill, act as educators, add to the knowledge pool, network with other practical experts, rebuke the other side's experts and finally present their position as clearly the only true one. Keeping in mind that expertise gives authority over a claim, the groups have an interest in gaining their own authority.

It should be noted that the distinction between the use of scientific and practical expertise in the debate was made for analytical purposes of this paper. In fact, they are closely interwoven in most arguments. This study's findings suggest that identifying experts solely with scientists is too narrow a view to understand the dynamics of a debate between private interest groups. Regarding the groups simply as citizen groups with lay knowledge reflects neither their self-representation nor the authority with which they act in the debate. Instead, the concept of the practical expertise captures what DRN and MSC claim to possess and how they act in relation with the lay public. The analysis of Act 13, embedded in the larger fracking debate, served to provide insights into how groups without policy-making power but who have an interest in policy output act to gain a say on a controversial issue. Expertise is a cornerstone in the construction of legitimacy in a debate. This is why this paper suggests to embrace a less restrictive view on expertise and to recognize that a more diverse range of groups regards themselves as experts and acts accordingly. This could add a new perspective to the current debate of expertise in society, politics and policy. 


\section{References}

1. Arthur, J.D., Bohm, B. \& Layne, M. (2008). Hydraulic Fracturing Considerations for Natural Gas Wells of the Marcellus Shale. Presented at the Ground Water Protection Council 2008 Annual Forum Cincinnati, Ohio.

2. Begos, K. (2012). Experts: Some Fracking Critics Use Bad Science. AP. Retrieved from http://bigstory.ap.org/ article/experts-some-fracking-critics-use-bad-science on 27 May 2014.

3. Berks Gas Truth, Clean Water Action, Delaware Riverkeeper Network, Earthworks, Clean Air Council, Damascus Citizens for Sustainability, Inc. \& Sierra Club PA Chapter (n.a., 2014). Proposed changes to Pennsylvania's oil and gas regulations: Key concerns and talking points. Retrieved from http://pennsylvania. sierraclub.org/PA_Chapter_2008/Conservation/Energy/Ch78TalkingPoints.PDF on 27 May 2014

4. Brasier, K.J., Filteau, M.R., McLaughlin, D.K., Jacquet, J., Stedman, R., Kelsey, T.W. \& Goetz, S.J. (2011). Residents' Perceptions of Community and Environmental Impacts from Development of Natural Gas in the Marcellus Shale: A Comparison of Pennsylvania and New York Cases. Journal of Rural Social Sciences, 26, 32-61.

5. Collins, H. \& Evans, R. (2007). Rethinking Expertise. London: The University of Chicago Press.

6. Delaware Riverkeeper Network (n.a., 2009b). The Truth about Natural Shale Gas Extraction in the Delaware River Watershed: What You Need to Know. Retrieved from http://www.delawareriverkeeper.org/resources/ Factsheets/Natural_Gas_Extraction_What_you_need_to_know.pdf on 27 May 2014.

7. Delaware Riverkeeper Network (n.a., 2012a). Annual Report 2012. Retrieved from http://www. delawareriverkeeper.org/resources/Reports/2012_AnnualReport_Final.pdf on 27 May 2014.

8. Delaware Riverkeeper Network (n.a., 2012b). The Basics about Pennsylvania's Act 13. Retrieved from http:// www.delawareriverkeeper.org/resources/Factsheets/talking\%20points\%20Act\%2013\%204.12.pdf on 27 May 2014.

9. Delaware Riverkeeper Network (2012C). Tell Your Pennsylvania Legislator What You Think! HB1950 is now law - Governor Corbett signed Act 13 Communities and the environment will pay the price. Retrieved from http://www.delawareriverkeeper.org/resources/Factsheets/Tell\%20your\%2oleg\%2owhat\%20you\%20 think\%2O-\%2OAct\%2013\%20and\%2Owhat\%20it\%2omeans3.12.pdf on 27 May 2014.

10. Delaware Riverkeeper Network (n.a., 2013). Press Release: White House Should Issue Executive Order Makint Water a National Priority, Shifting U.S. to Clean Energy Future. Retrieved from http://www.delawareriverkeeper. org/resources/PressReleases/Executive_Order_PR\&EO_July2013.pdf on 27 May 2014.

11. DeRosa, D. (2013). Fracking by the Numbers. Retrieved from http://www.environmentnewjersey.org/ news/nje/fracking-numbers-new-environment-new-jersey-report-first-quantify-threat-gas-drillingshows on 27 May 2014.

12. Fischer, F. (2000). Citizens, Experts and the Environment. The Politics of Local Knowledge. Durham \& London: Duke University Press.

13. Garber, A., Van Rossum, M., Feridun, K., Bernhardt, S. \& Bloom, I.M. (2013). 100,000 Signatures for a Moratorium on Fracking Delivered to Gov. Tom Corbett. Retrieved from http://www.pennenvironment.org/ news/pae/1000oo-signatures-moratorium-fracking-delivered-gov-tom-corbett on 27 May 2014. 
14. Goho, S.A. (2012). Municipalities and Hydraulic Fracturing: Trends in State Preemption. Planning \& Environmental Law, 64, 3-9.

15. Hartelius, E.J. (2008). The Rhethoric of Expertise. Ann Harbor: ProQuest.

16. Harper, J.A. (2008). The Marcellus Shale - An Old "New" Gas Reservoir in Pennsylvania. Pennsylvania Geology, 28.

17. Hicks, M. (2012). 'Frack Nation' digs up the not-so-scary truth. The Washington Times. Retrieved from http://p.washingtontimes.com/news/2012/feb/14/hicks-frack-nation-digs-up-the-not-so-scary-truth/\#. TzsGOjcF6Ao.twitter on 27 May 2014.

18. Hilgartner, S. (2000). Science on Stage: Expert Advice as Public Drama. Stanford: Stanford University Press.

19. Kargbo, D.M., Wilhelm, R.G. \& Campbell, D.J. (2010). Natural Gas Plays in the Marcellus Shale: Challenges and Potential Opportunities. Environmental Science and Technology, 44, 5679-5684.

20. Kincaid, H., Dupré, J. \& Wylie, A. (2007). Value-Free Science? Ideals and Illusions. Oxford: Oxford University Press.

21. Marcellus Shale Coalition (n.a., n.d.). Request a Speaker. Retrieved from http://marcelluscoalition.org/getinvolved/request-a-speaker/ on 25 May 2014.

22. Marcellus Shale Coalition (n.a., 2012a). Fact Check: Despite Baseless Claims, New PA Natural Gas Law Heightens Fracturing Disclosure. Retrieved from http://marcelluscoalition.org/2012/04/fact-checkdespite-baseless-claims-new-pa-natural-gas-heightens-fracturing-disclosure/ on 27 May 2014.

23. Marcellus Shale Coalition (n.a., 2012b). MSC Statement on White House Hydraulic Fracturing Executive Order. Retrieved from http://marcelluscoalition.org/2012/o4/msc-statement-on-white-house-hydraulicfracturing-executive-order/ on 27 May 2014.

24. Marcellus Shale Coalition (n.a., 2012c). MSC Releases Recommended Practice for Pre-Drill Water Sampling. Retrieved from http://marcelluscoalition.org/2012/08/msc-releases-recommended-practice-for-predrill-water-sampling/ on 27 May 2014

25. Marcellus Shale Coalition (n.a., 2012d). Tweet @EPAgov water well tests "found NONE with unsafe levels of contamination tied to fracturing". Retrieved from http://marcelluscoalition. org/2012/05/201013519506874368/ on 27 May 2014.

26. Marcellus Shale Coalition (n.a., 2013a). Just The Facts: A Closer Look at Duke's Methane Study. Retrieved from http://marcelluscoalition.org/2013/06/just-the-facts-a-closer-look-at-dukes-methane-study/ on 27 May 2014.

27. Marcellus Shale Coalition (n.a., 2013b). Just The Facts: Despite Claims, Pa. Farmers Reaping Huge MarcellusRelated Benefits. Retrieved from http://marcelluscoalition.org/2013/01/just-the-facts-despite-claims-pafarmers-reaping-huge-marcellus-related-benefits/ on 27 May 2014.

28. Marcellus Shale Coalition (n.a., 2013c). MSC Statement on 2012 Pa. Natural Gas Impact Fee Revenue. Retrieved from http://marcelluscoalition.org/2013/04/msc-statement-on-2012-pa-natural-gas-impactfee-revenue/ on 27 May 2014. 
29. Marcellus Shale Coalition (n.a., 2013d). MSC, PIOGA to Study Radioactivity Levels in Shale Operations. Retrieved from http://marcelluscoalition.org/2013/11/msc-pioga-to-study-radioactivity-levels-in-shaleoperations/ on 27 May 2014.

30. Marcellus Shale Coalition (n.a., 2013e). ICYMI: SHALE INSIGHTT 2013 Highlights. Retrieved from http:// marcelluscoalition.org/2013/og/icymi-shale-insight-2013-highlights/ on 27 May 2014.

31. Martin, T.G., Burgman, M.A., Fidler, F., Kuhnert, P.M., Low-Choc, S., McBride, M. \& Mengersen, K. (2011). Eliciting Expert Knowledge in Conservation Science. Conservation Biology, 1-10.

32. McChesney, C. (2012). Cornell professor: Switching from coal to natural gas would cut greenhouse gases 40 percent. Syracuse. Retrieved from http://www.syracuse.com/news/index.ssf/2012/o7/cornell professor_switching_fr.html on 29 May 2014.

33. Pielke, R.A. Jr., (2007). The Honest Broker: Making Sense of Science in Policy and Politics. Cambridge: Cambridge University Press.

34. Rabe, B.G. \& Borick, C. (2013). Conventional Politics for Unconventional Drilling? Lessons from Pennsylvania's Early Move into Fracking Policy Development. Review of Policy Research, 30, 321-340.

35. Robinson Township Case (J-127A-D-2012). Appeal from the Order and Opinion of the Commonwealth Court at No. 284 MD 2012, dated July 26, 2012, in the Supreme Court of Pennsylvania.

36. Rothstein, B. \& Stolle, D. (2003). Social Capital, Impartiality and the Welfare State: An Institutional Approach. In: Hooghe, M. \& Stolle, D. (Eds.). Generating Social Capital: Civil Society and Institutions in Comparative Perspective. New York: Palgrave McMillan.

37. Shale Gas Outrage (2012). The Water Footprint of Shale Gas Development. Retrieved from http:// protectingourwaters.wordpress.com/2012/og/o6/the-water-footprint-of-shale-gas-development/ on 15 May 2014.

38. Smith, M.F. \& Ferguson, D.P. (2013). “Fracking democracy”: Issue management and locus of policy decisionmaking in the Marcellus Shale gas drilling debate. Public Relations Review, 39, 377-386.

39. Soeder, D.J. \& Kappel, W.M. (2009). Water Resources and Natural Gas Production from the Marcellus Shale. USGS Fact Sheet 2009-3032. Baltimore, MD: U.S. Geologic Survey.

40 Steinzor, N., Van Rossum, M., Carluccio, T., Bloom, I.M. \& Hvozdovich, S. (2012). Organizations Demand PADEP Reveal all Data from Water Tests, Provide Information to Homeowners. Retrieved from http://www. delawareriverkeeper.org/resources/PressReleases/PR\%2oWater\%2otesting\%2oletter\%20final\%2O-\%20 combined\%20for\%20web\%2011\%2013\%2012.pdf on 27 May 2014.

41. Van Rossum, M. (2013a). Delaware Riverkeeper Network Premieres New Installment of Shale Truth Interview Series On Wednesday, August 21st. Retrieved from http://www.delawareriverkeeper.org/resources/ PressReleases/ShaleTruth_New_Installment_Premieres_Aug_21.pdf on 29 May 2014

42 Van Rossum, M. \& Carluccio, T. (2012a). Press Release Delaware Riverkeeper Network Calls on Pennsylvania Senator Chuck Mcllhinney to Retract Misinformation in His Statements Regarding Act 13. Retrieved from http://www.delawareriverkeeper.org/resources/PressReleases/press\%2orelease\%20re\%20Mcllhinney\%20 Itr2\%2024\%2012.finaldocx.pdf on 27 May 2014. 
43. Van Rossum, M. \& Carluccio, T. (2012C). Television Ad Airs in Philadelphia Region Fighting Back Against Gas Industry Immediate Goal: "Stop Fracking Now". Retrieved from http://www.delawareriverkeeper.org/ resources/PressReleases/2012-09-11_TV_Ad\%2O_in_Phila_area.pdf on 27 May 2014.

44. Van Rossum, M. \& Hein, K. (2012). Press Release New Report Raises Red Flag for Bats from Shale Gas Drilling. Retrieved from http://www.delawareriverkeeper.org/resources/PressReleases/PR_bats_\&_gas_ drilling\%2opress.pdf on 27 May 2014.

45. Veatch, R.W. Jr., Moschovidis, Z.A. \& Fast, C.R. (1989). An Overview of Hydraulic Fracturing. In, S.A., Nierode, D.E. \& Veatch, R.W. Jr., (Eds.). Recent Advances in Hydraulic Fracturing, Edited by Gidley, J.L., Holditch. Society of Petroleum Engineers.

46. WJACTV (n.a., 2012). Seneca Resources Gives Johnstown TV Station an Eye \& Earful. Retrieved from http:// marcellusdrilling.com/2012/11/seneca-resources-gives-johnstown-tv-station-an-eye-earful/ on 27 May 2014.

47 Wolfgang, B. (2012). EPA declares water in Pa. town safe to drink despite fracking. The Washington Times. Retrieved from http://t.co/OMBfmu7y on 20 May 2014.

48. Wynne, B. (1996). May the Sheep Safely Graze? A Reflexive View of the Expert-Lay Knowledge Divide. In: Lash, S., Szerszynski, B. \& Wynne, B. (Eds.). Risk, Environment and Modernity: Towards a New Ecology. London: Sage. 